Bu makaleye atıfta bulunmak için/To cite this article:

ADA, Ș. GÜLTEKİN, S. GÖNENÇ, H. (2021). Eğitim Fakültesi Öğrencilerinin E-Öğrenmeye Yönelik Tutumlarının İncelenmesi. Atatürk Üniversitesi Sosyal Bilimler Enstitüsü Dergisi, 25 (4), 1738-1761.

\title{
Eğitim Fakültesi Öğrencilerinin E-Öğrenmeye Yönelik Tutumlarının İncelenmesi
}

\author{
Sükrü $A D A^{(*)}$ \\ Sevil GÜLTEKIN ${ }^{(* *)}$ \\ Hale GÖNENÇ ${ }^{(* * *)}$
}

Öz: Covid-19 salgınından en çok etkilenen sistemlerden birisi de eğitim sektörüdür. Yüksek Öğretim Kurumları alışılagelmiş eğitim ortam ve yöntemlerini hızlı bir şekilde değiştirmek ve dönüşürrmek zorunda kalmışlardır. Bu araştırmada Ĕgitim Fakültesi ve Eğitim Bilimleri Enstitüsü ögrencilerinin Covid-19 pandemi sürecinde almış oldukları e-öğrenmeye yönelik tutumlarının incelenmesi amaçlanmıştır. Araştırmanın çalışma grubunu 2020-2021 yılında Uludağ Üniversitesi Ĕ̌itim Fakültesi ve Eğitim Bilimleri Enstitüsünde ögrrenim gören ve çalışmaya rastlantısal örnekleme yöntemiyle katılan 124 ögrenci oluşturmaktadır. Veri toplama aract olarak; Eögrenmeye yönelik tutumlarını ölçmek için Kisanga (2016) tarafindan geliştirilen, Biçer (2019) tarafindan Türkçeye uyarlanan "E-Öğrenmeye Yönelik Tutum Ölçeği" kullanılmıştır. Araştırmada, veri toplama ve analiz süreçlerinde nicel araştırma tasarımlarından betimsel tarama modeli kullanılmıştır. Araştırmada lisans ve yüksek lisans öğrencilerinin çoğunluğunun erişimini evindeki bilgisayar ve telefondan karşıladiğl görülmüş̧ür. Elektronik cihaz kullanma düzeyi çok yeterli ve yeterli olan ögrencilerin memnuniyet ve teknoloji kullanma ĕgilimlerinin yüksek olduğu görülmüş̧ür. Yüksek lisans öğrencilerinin lisans öğrencilerine göre e-öğrenmeden memnuniyet ve motivasyon ortalamalarının daha yüksek olduğu saptanmıştır. Öğrenciler herhangi bir iște çalışıyorsa e-ögrrenmeden memnun olduğu ve bu durumun da motivasyonu yükselttiği görülmüşü̈r. E-öğrenme, çalışanların eğitim hayatlarına devam etmelerine firsat tanımaktadır. Programların saatlerinin çalışanlara göre planlanması önerilmektedir.

Anahtar Kelimeler: Covid-19, eğitim bilimleri, e-öğrenme.

\section{Investigation of the Attitudes of Education Faculty Students Towards E-Learning}

Abstract: One of the sectors most affected by the Covid-19 pandemic is the education sector. Higher Education Institutions have had to quickly change and transform their usual educational

${ }^{*}$ Prof. Dr. Bursa Uludağ Üniversitesi Eğitim Fakültesi Eğitim Bilimleri Bölümü (e-posta: sukruada@uludag.edu.tr) (D ORCID ID. https://orcid.org/0000-0003-3329-9494

**) Öğretmen, Milli Eğitim Bakanlığı Bursa Şehit Erol Olçok Mesleki ve Teknik Anadolu Lisesi (e-posta: sevil_2302@hotmail.com) ORCID ID. https://orcid.org/0000-0001-5742-2800 ***)Öğretmen, Milli Eğitim Bakanlığı Bursa Modern Bahçe Şehir Koleji (e-posta: hale.gonenc@bahcesehir.k12.tr) (D) ORCID ID. https://orcid.org/0000-0002-4125-6446

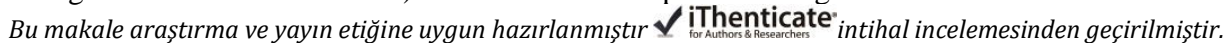


environments and methods In this study, it was aimed to examine the attitudes of the students of the Faculty of Education and the Institute of Educational Sciences towards e-learning during the Covid-19 pandemic process. The study group of the study consists of 124 students who study at Uludağ University Faculty of Education and Institute of Educational Sciences in 2020-2021 and participate in the study voluntarily. As a data collection tool; In order to measure their attitudes towards e-learning, "Attitude Scale Towards E-Learning" developed by Kisanga (2016) and adapted into Turkish by Biçer (2019) was used. In the research, descriptive survey model, one of the quantitative research designs, was used in data collection and analysis processes. In the study, it was observed that most of the undergraduate and graduate students met their access from their home computer and phone. It has been observed that students whose level of using electronic devices are very adequate and sufficient have a high level of satisfaction and technology use. Graduate students' satisfaction with e-learning and motivation averages were found to be higher than undergraduate students. It has been observed that if students are working in any job, they are satisfied with e-learning and this situation increases motivation. E-learning provides an opportunity for employees to continue their education. It is recommended that the hours of the programs are planned according to the employees.

Keywords: Covid-19, educational sciences, e-learning.

Makale Gelis Tarihi: 14.07.2021

Makale Kabul Tarihi: 09.12.2021

DOI: 10.53487/ataunisosbil.971183

\section{Giriş}

Günümüzde tüm eğitim kurumları farklı biçimlerde internet ve ağ teknolojilerinden istifade etmektedir. Salgın dönemi ile beraber bu süreç her yaştan kişi için mecbur hale gelmiştir. Salgın ile birlikte e-öğrenme yaklaşımı yaygın bir biçimde kullanılmaya başlanmıştır.

Toplumun tarihsel geçmişi, sosyal yaşam, ekonomik ve kültürel yapısı, teknolojik olanaklar gibi birçok faktör toplumun eğitim algısını değiştirmiştir (Şişman, 2007). Eğitim süreci sürekli değişmekte ve toplumu doğrudan etkilemektedir. Yaşadığımız süre boyunca, işlevsellik ve pratiklik kazanmak için eğitim şarttır. Günümüzde her zaman ve her yerde bilgiye olan talep, eğitimi zamandan ve mekândan bağımsız hale getirmiş ve alternatif eğitim fırsatları yaratmıştır. Bu süreci etkileyen en önemli faktörler teknolojik gelişme ve firsatlardır. İnternet hızla kullanıldı ve eğitimdeki rolünü de gösterdi. Geçmişte uzaktan eğitim mektuplarla verilirken artık internet altyapısının gelişmesi ve teknik araçların artmasıyla uzaktan eğitim değişti. Eğitim elektronik ortama geçtikçe, bireyler kendi öğrenme ihtiyaçlarını yönetmeye başlar. Tüm dünyayı etkileyen COVIID19 salgını en başta sağlık sektörü olmakla birlikte, sosyal, ekonomik, siyasi alanlarının yanında eğitim sektörünü de ciddi bir şekilde etkilemiştir. Bununla birlikte e-öğrenmenin önemi ortaya çıkmıştır.

Hükümetin 12 Mart 2020 tarihli kararına göre, 16 Mart'tan itibaren ülkemdeki tüm yükseköğretim kurumları eğitime bir hafta ara verdi. Salgın sırasında, üniversiteler İnternet ve ağ teknolojilerinin farklı şekillerde kullanılmasını zorunlu kıldılar. Daha önce öğretim teknolojisi ile desteklenen derslerin her düzeyde daha popüler hale gelmesi ve 
e-öğrenme yöntemlerinin tüm eğitim kurumlarında kullanılması beklenmektedir ancak bu salgının gerçekliği bu beklentiyi yerine getirmektedir. Zorunlu ve evrensel bir şekilde yapılmıştır (Gülbahar, 2021).

Bulaşıcı hastalıkların toplumda yayılmasını azaltmak için önemli bulaşma zincirlerini kırarak bulaşma yollarını azaltmak için eğitim kurumlarının kapatılması önerisi dikkate alınarak karar verilmiştir. Ayrıca üniversitelerin içerik ihtiyaçlarının tazmin edilmesi için İstanbul Üniversitesi, Anadolu Üniversitesi ve Atatürk Üniversitesi ders kütüphanelerinde dijital ortamda bulunan tüm dersler YÖK Dersleri adı verilen bir ara yüz üzerinden açık ve erişilebilir (23 Mart itibarıyla ). Üniversitenin dijital ders materyallerinin bu havuza eklenmesine karar verildi (Anadolu Ajans1, 2020).

Hepimizin bildiği gibi, Covid-19 salgınından önce birçok üniversitede uzaktan eğitim araştırması yapıldı. Bazı öğretmenler, özellikle büyük derslerde kaydolmak için kendi elektronik içeriğini kullanırken, diğerleri tersine çevrilmiş sınıf yaklaşımını kullanır. Bu etkinliklerde, öğretim üyeleri ve personel videoya kaydedilen ders içeriğinin teorik arka planını tanıttığında, açık soru ve alıştırmalardan oluşan yüz yüze kurs sırasında da destekleyici bir e-öğrenme sistemi kullandılar. Ancak, üniversiteler, öğretim görevlileri ve ögrenciler için gerekli tüm dersleri kapsamaz. E-kurs uygulaması, Covid-19 salgını ile gündem haline geldi ve yüz yüze eğitimdeki boşlukları doldurmak için e-kursları değiştirmeye çalışıyor, bu da teknolojiyi daha sistematik ve zorunluluklar nedeniyle bir eğitim aracı haline getiriyor (Atasoy, Özden, ve Kara, 2020).

Eğitim sisteminin dijital değişimi, e öğrenmek için yeni bir öğretim öğrenme ortamına izin verilmiştir. Dünyadaki ve Türkiye'de e-öğrenme uygulamaları birçok klasik öğrenme yöntemini değiştirmeye başlamıştır. Bu bağlamda, eğitimin çözümlerini ve özelliklerini çözme sorunlarını çözmenin alternatif bir yoludur. Son birkaç yılda, dijital medya öğrenme ve öğrenme deneyimlerini tanıttı ve üniversite öğrencileri ile öğretim görevlileri arasında ortaklaştı (Paechter, Maier, \& Macher, 2009).

Teknoloji tabanlı e-öğrenme, öğrenme materyalleri üretmek, öğrencilere öğretmek ve ayrıca bir organizasyondaki kursları düzenlemek için internetin ve diğer önemli teknolojilerin kullanımını kapsar (Fry, 2001). E-öğrenme, büyük miktarda bilgiye erişim kolaylığı ile bilgi ve niteliklerin etkililiğini arttırmaktadır.

Teknoloji gelişimi kavramı, farklı boyutlara devredilmiştir (Özbay, 2015). Bu, insanların bilincinde önemli olan hayatlarının gelişimine katkıda bulunmasıdır. Elektronik seviyesi ve yöntemleri, eğitimi ve eğitim yöntemini eğitme yöntemi olarak kullanılmıştır. Elektronik eğitim, ülkelerin, kurumların ve hatta kendi gündemlerinin uyarlanabilirliğini değerlendirebilir.

Araştırmacılardan bazıları, e-öğrenme ortamında öğrencilerin memnuniyetinin arttığına yönelik sonuçlar aldığını bildirmişlerdir (Klein, Noe \& Wang, 2006). Öte yandan Zhan \& Mei (2013), akademik benlik kavramı ve toplumsal etkileşimin emsal derecede önemli olmamakla birlikte, akademik performans ve memnuniyetle yakından ilgili önemli faktörler olduğu neticesine ulaşmışlardır. Holder (2007), öğrenci motivasyonu ve arzusuna ek olarak, ders konularının ve e-öğrenmenin kabul edilmesinin de öğrenci memnuniyetini artırmaya yardımcı olabileceğine inanmaktadır. Ancak e- 
öğrenme ortamında yapılan araştırmada; öğrencilerin coşkusunun (Yang, Tsai, Kim, Cho \& Laffey, 2006; öğrencilerin donanım ve yetenekleri (Pena \& Yeung; 2010), önemli faktörler olduğu sonucuna varmışlardır. Akademik ve idari personelin yetenek düzeyi (Machado, 2007) öğrenci memnuniyetini etkilemektedir (Gülbahar, 2012). E-öğrenme ortamlarında öğrencilerin tümüyle bir sürece ilişik fikirlerini ortaya koyması bakımından memnuniyetlerinin önemli olduğunu belirtmekte ve öğrenenlerin motivasyonlarının düzenli şekilde test edip yeni düzenlemeler yapılmalıdır.

E-öğrenmenin avantajlarını ve dezavantajlarını açıklayan genel literatür, yüksek öğretimde e-öğrenmenin uygulanmasının gerekliliğinin fakülte, personel, idareciler ve öğrencilerin e-öğrenmenin tüm faydalarından yararlanmalarını sağlamak olduğunu göstermektedir.

Bunula beraber, covid-19 salgını sürecinde dünya çapında üniversitelerin farklı uygulamaları olmakla beraber e-ders uygulamalarına uzak coğrafi bölgelerden, evlerden katılım sağlanabilmesi en önemli avantajlarından birisi olarak görülmektedir. İstenilen zamanda ders kayıtlarının tekrar izlenilebilmesi ve öğrencilerin ders haricinde öteki işlerine daha fazla zaman ayırabilmesi, okula fiziki ulaşımdan vakit ve enerji tasarrufu sağlanması ve çevrimiçi sınav uygulamaları benzer biçimde esneklikler e-öğrenme uygulamalarının müspet yüzü olarak ortaya çıkmaktadır (Atasoy, Özden, ve Kara, 2020).

E-öğrenme, öğrencilerin veya öğrenicilerin seyahat etmesine gerek olmaması anlamında maliyet etkindir. Ayrıca, çok sayıda binaya ihtiyaç duymadan maksimum sayıda öğrenci için öğrenme firsatları sunması açısından da uygun maliyetlidir.

Ülkemizde yükseköğretime devam edenlerin salgın hastalık zamanındaki problemlere ait araştırmada, uzaktan eğitim uygulamalarında bilgisayar ve internete erişimde güçlüklerle karşılaşıldığı, özel yükseköğretim kurumları harçlarını ödemekte güçlüklerin olduğunu ve öğrenci burslarını yeterli olmadığını belirtmişlerdir. Ana hatlarıyla öğrenciler, online derslerin çokça izlenebilmesi bakımından yarar sağladığı, okul dışında ev ortamında proje ve ödevleri yapmanın konforunu belirtmişlerdir. Öğrencilerden bazıları ise uzaktan eğitimin, örgün öğrenime bakılırsa yetersiz kaldığını savunmuşlardır (Duygun, 2020) .

Araştırma Problemi: Uzaktan eğitim programlarına devam eden Eğitim Fakültesi ve Eğitim Bilimleri Enstitüsü öğrencilerinin e-öğrenme ile ilgili tutumları farklı değişkenlere göre incelemek ve farlılık olup olmadığını saptamaktır olarak belirlenmiş ve aşağıdaki alt problemler incelenmiştir.

\section{A. Araştırmanın Alt Problemleri}

1- İnternet erişim imkanlarına (pc, internet, akıllı telefon...)

2- Bilgisayar kullanım becerilerine,

3- Devam ettikleri programlara,

4- Bir işte çalışıp çalışmadıklarına göre farklılık göstermekte midir? 
Ĕ̆itim Fakültesi Öğrencilerinin E-Öğrenmeye Yönelik Tutumlarının Incelenmesi

\section{Araştırmanın Amacı}

Bu araştırmanın amacı, Eğitim Fakültesi ve Eğitim Bilimleri Enstitüsü öğrencilerinin uzaktan eğitime yönelik tutumlarını farklı değişkenlere göre incelenmesidir.

\section{Kuramsal Çerçeve}

\section{A. E-öğrenme Kavramı}

Telekomünikasyon ve bilgisayar teknolojilerinin gelişimi birlikte internetin yaygınlaşması, iletişim alanını olduğu kadar eğitimi de etkilemiştir. Her ne kadar uzaktan eğitimin tarihi 1700'lere dayansa da 1990'lardan sonra internetin ortaya çıkması ve teknolojik gelişmelerin artmasıyla birlikte uzaktan eğitimin şeklide değiştirmiştir. Bu değişiklikler yeni kavramların ortaya çıkmasına sebep olmuştur. Artık uzaktan eğitim genel bir kavram olmuş, eğitimin uygulanış şekline göre isimlendirilmiştir. Dijital platformların hayatımızın bir parçası haline gelmesiyle birlikte bazı kavramların başına elektronik kelimesinin ilk harfi olan "e-" eki eklenerek (e öğrenme, e-ticaret, e-devlet vs.) kavramlara yeni bir boyut kazandırmıştır (Gökdaş ve Kayri, 2005). Bu durum eğitim sektöründe elektronik öğrenme (e-öğrenme) olarak karşımıza çıkmaktadır.

Nalbant (2006) e-öğrenmeyi bir network sistemi kullanarak bilgi transferinin ve etkileşimin olduğu öğrenme şekli olarak tanımlamaktadır. Farklı kaynaklarda eöğrenmenin teknoloji tabanlı öğrenme olarak da ele alındığını belirten Arat (2011) e öğrenmeyi, sanal sınıfların ve sayısal teknolojilerinin iş birliğiyle oluşturulan bir tür uygulama ve süreç olarak görmektedir. Başka bir tanımla e-öğrenme; internet, intranet, ses ve görüntü kasetleri, televizyon yayınları ve CD-DVD gibi ortamların yardımıyla istenilen zaman ve mekânda, bilgi ve yetenekleri öğrenme sürecidir (Govindasamy, 2002). Geniş bir tanımla e-öğrenme, bireyin kendi öğrenmesini planlayarak, zaman veya mekân kısıtlaması olmadan, bir bilgisayar ağı veya internet üzerinden senkron veya asenkron şekilde diğer öğrenen veya öğreten ile iletişime geçip, bilgisayar teknolojisinin sağlamış olduğu olanakla görsel veya işitsel etkileşime geçebildiği, bireye yaşam boyu öğrenme firsatını tanıyan bir öğrenme şekli olarak tanımlamıştır (Demir, 2013). Kısaca, teknolojinin kullanımının esas alan bu eğitim şekli, "sanal öğrenme”, "internete dayalı öğretim”, "sanal öğretim”, “çevrimiçi öğrenme” gibi farklı isimlerle de adlandırılmaktadır (Karahisar, 1999).

\section{B. E-öğrenme Türleri}

E-öğrenme, teknolojinin gelişimiyle birlikte özel bir kavramdan bünyesinde birçok öğrenme yöntemini barındıran bir kavram haline gelmiştir. E-öğrenme, yapılacak öğretimin gerçekleşme zamanına göre iki farklı yöntemi vardır. Bunlar:

\section{Asenkron E-öğrenme}

Asenkron eğitim uygulamaları eğitime katılanların, eğitimi düzenleyenlerden bağımlı olmadan arzu ettiğinde derse katılıp öğrencinin uygun gördüğü zamanda dersi sonlandıracak biçimde düzenlenmiş eğitim platformudur. Bu öğretim biçimi eğitim uygulamalarında öğretmenine yeni roller getirmektedir; bu bağlamda öğretmen rehberlik 
ve liderlik görevini yerine getirmektedir. Bu öğrenme durumlarında, öğretmen merkezli değil öğrenen merkezli öğrenme ortamları oluşturulmaktadır (Can , 2008).

\section{Senkron E-öğrenme}

Eşzamanlı öğrenme, hem öğrenenlerin hem de öğretmenlerin çeşitli şekillerde bir araya geldiği sanal bir sınıf sistemidir. Senkron etkileşim denilince, eğitim sürecinin zamana bağlı olarak aynı yerde ve yüz yüze olduğu düşünülür. Sürekli değişen teknoloji sayesinde pratikte daha yaygın olan bu iletişim süreci kategorisine artık web tabanlı eğitim uygulamalarını da dahil edebiliyoruz. Çünkü eğitim alan ve veren tarafların görüntü ve sesleri internet veya intranet üzerinden iletilebilmekte ve sağlanan iletişim ile senkronize bir eğitim ortamı oluşturulabilmektedir. Bu durumda öğrencilere sanal bir sınıfta olma hissi verebilir. Bu ortamın en önemli avantajı, "öğrenci-öğrenci" ya da "eğitmen-öğrenci" etkileşimini sağlayabilecek araçların kullanımına uygun olması nedeniyle sıradan sınıf eğitiminin vazgeçilmez tartışma ortamını eğitim ortamına aktarabilmesidir. (Özkaraca, 2005).

Senkron e-öğrenme ortamlarında ders oturumları tekrar izlenebilmesi için kaydedilebilir. Öğrenen ve öğretenin aynı anda çevrimiçi olması aralarındaki iletişimi artırmakta ve iş birlikçi eğitimin sağlanmasına imkân tanımaktadır (Bahçekapılı, 2010).

\section{E-öğrenmeyle İlgili Kavramlar}

Globalleşen dünya, zaman içinde diğer alanları olduğu gibi eğitimi de etkilemiştir. Siyasal, ekonomik, iktisadi, ülkelerin gelişmişlik düzeyi ve teknolojideki hızlı gelişmeler eğitim alanında değişikliklere gidilmesine neden olmuştur. Kısacası zaman içerisinde toplumu etkileyen her türlü gelişme eğitim anlayışının da değişmesine neden olmaktadır. Buna örnek olarak ise internet kullanımının hızla yaygınlaşmasıyla ortaya çıkan "eöğrenme" kavramı verilebilir. E-öğrenme kavramının ortaya çıkma sürecini takip eden birçok farklı eğitim uygulaması karşımıza çıkmaktadır. E-öğrenme için uzaktan eğitim temel alınırken, uzaktan eğitimin ardından bilgisayar tabanlı eğitim, web tabanlı eğitim gelmektedir.

\section{Uzaktan Eğitim}

Uzaktan eğitim, öğrenciler ve öğretmenler arasındaki çeşitli iletişim ve etkileşim ortamlarının, sınıfın sinırlılıkları nedeniyle geleneksel öğrenme ortamında gerçekleştirilemeyen eğitimi planlamak ve sağlamak için özel olarak düzenlendiği bir öğretim yöntemidir (Alkan, 2019).Uzaktan eğitim, öğrenciler ve öğretmenlerle yüz yüze görüşmek zorunda kalmadan, çeşitli iletişim araçlarının kullanılmasıyla bir merkezden yürütülen bir eğitim şeklidir (TDK, 2020).

(Kırık, 2014) araştırmasında uzaktan eğitim, planlı bir şekilde yürütülen ve yeni iletişim teknolojileri ile desteklenen hiyerarşik, istikrarlı, karmaşık ve doğrusal olmayan bir eğitim sistemi olarak tanımlanmaktadır. Uzaktan eğitim, geleneksel eğitimden farklıdır, çünkü ikincisi, öğrencilerin aynı yerde veya belirli bir zamanda olmalarını gerektirmez ve bilgi ve iletişim teknolojisi (ICT) kullanılarak eşzamanlı (eşzamanlı) veya eş zamansız olarak sürdürülebilir. Eşit firsatlar ve yaşam boyu öğrenme firsatları planlı bir eğitim şeklidir (Çalışkan, 2019). 


\section{Bilgisayar Destekli Öğretim}

Bilgisayar destekli eğitim ve bilgisayar destekli öğretim birbirinin yerine kullanılabilen iki kavram olmasına rağmen, anlam bakımından farklıdır. Bilgisayar Destekli Eğitim (BDE) ile Bilgisayar Destekli Eğitim (BDI) arasındaki fark, kurslar dahil diğer alanları kullanmasıdır. BDE'de öğretime ek olarak rehberlik hizmetleri, okul yönetimi araştırmaları gibi başka alanlar da bulunmaktadır (Camnalbur, 2008).Öte yandan, BDI, bir bilgisayarın bir öğrenme ortamı olarak kullanıldı ̆̆ı bir öğretim biçimi olarak ifade edilir. Bilgisayar teknolojisi ve kendi kendine çalışma ilkelerinin kombinasyonu öğrencilerin öğrenme motivasyonunu arttırır. Süreç, öğrenciler ve bilgisayar kullanan dersler tarafından programlanır. Yazılım (Engin, Tösten ve Kaya, 2010).

\section{Web Tabanlı Öğretim}

İnternetin tüm dünyada yaygınlaşması ile birlikte uzaktan eğitimin şekli de değişmiş ve bilişim teknolojilerindeki her yeni gelişme öğretime yeni bir boyut kazandırmaktadır. Eğitim, internet sayesinde artık daha esnek bir yapıya kavuşmuş, öğrencilere farklı imkânlar sunarak öğrenciyi bireysel olarak daha özgür ve etkin bir hale getirmiştir. Eğitimde internet teknolojilerinin daha etkin bir şekilde kullanılmaya başlanmasıyla birlikte ortaya birtakım yeni terim ve ifadeler çıkmıştır. Bunlardan bazıları internet tabanlı öğretim, çevrimiçi öğretim, web tabanlı öğretim olarak sayılabilir.

\section{Yöntem}

Bu araştırmada, Bursa Uludağ Üniversitesi Eğitim Fakültesi ve Eğitim Bilimleri Enstitüsü öğrencilerinin e-öğrenme tutumlarının çeşitli değişkenler açısından incelenmesi araştırıldığından, veri toplama ve analiz süreçlerinde nicel araştırma tasarımlarından betimsel tarama modeli kullanılmıştır. Betimsel tarama modeli, geçmişte ya da güncel olarak var olan bir durumu mevcut haliyle tasvir etmeyi amaçlayan araştırma yaklaşımıdır (Karasar, 2020).

\section{A. Veri Toplama Aracı}

Araştırmada kullanılan veri toplama aracı iki kısımdan oluşmaktadır. Aracın birinci bölümünde devam ettiği program, öğrenimi yanında herhangi bir işte çalışıp çalışmadığı, elektronik cihazları (telefon, bilgisayar...) kullanma konusunda becerileri, kaldığı yerde internete erişim imkânı, internet temelli öğrenme etkinliklerine nereden erişime sahip olma durumlarına göre demografik bilgileri değerlendirilmiştir. Veri toplama aracının ikinci bölümünde e-öğrenme yönelik tutum ölçeği kullanılmıştır.

Kisanga (2016) tarafından geliştirilen ve Biçer (2019) tarafından Türkçeye uyarlanan "E-Öğrenmeye Yönelik Tutum Ölçeği” öğrencilerin e-öğrenmeye yönelik tutumlarını ölçmek için kullanılmıştır. Dörtlü Likert tipinde toplam 36 madde ve dört faktörden oluşmaktadır. Ölçek 23 maddeden oluşmakta ve dört faktörlü bir ölçeğe dönüştürülmüş̧ür. $\mathrm{Bu}$ projelerin bilgi ve iletişim teknolojilerinin kullanımına ilişkin ifadeler içerdiği gözlemlenmiştir. Bu ifadelerin katılımcıların teknoloji kullanma eğilimini gösterdiği düşünüldüğünde birinci faktör (F1) "teknolojiyi kullanma eğilimi" 
olarak adlandırılmaktadır. İkinci faktör için maddeler incelendiğinde teknolojinin ve eöğrenme ortamının ekonomik kullanımı, kalite iyileştirme, basitlik ve eğlence gibi ifadeleri içerdiği görülmektedir. Aslında bu ifadeler, ikinci faktör (F2) "memnuniyet" olarak adlandırılan, katılımcıların teknoloji ve e-öğrenme ortamına ilişkin olumlu görüşlerini içermektedir. Üçüncü faktörü içeren maddeler incelendiğinde heyecan, verimlilik, BİT kullanımı, e-öğrenme tercihleri gibi öğrenmeyi etkileyen tahminleri içerdiği görülmektedir. Bu anlamda bu maddelerin e-öğrenmeye yönelik motivasyonu artıracağı düşünüldüğünde üçüncü faktör (F3) "motivasyon" olarak adlandırılmaktadır. Dördüncü faktör (F4) "kullanılabilirlik" olarak ifade edilir. Çünkü bu projelere baktığımızda BİT kullanımı ve e-öğrenme ile ilgili ifadeleri görebiliyoruz. Bu anlamda birinci faktör (F1) "teknik kullanım eğilimi”, ikinci faktör (F2) "memnuniyet”, üçüncü faktör (F3) ise "motivasyon" olarak adlandırılmaktadır. Dördüncü faktör (F4) "teknik eğilim" olarak adlandırılmaktadır (Bissell, 2019). "Uygulama" kullanılarak hazırlanan ölçekler paylaşılmakta ve araştırmaya gönüllü olarak katılan bireylere paylaşılan bir link üzerinden iletilmektedir.

\section{B. Verilerin Analizi}

Araştırmanın amacı kapsamında öğrencilere "E-Öğrenmeye Yönelik Tutum Ölçeği" uygulanmıştır. Uygulanan veri toplama aracından elde edilen veriler SPSS 22 (Statistical Package for Social Science) programında işlenerek analiz edilmiştir.

Çalışma grubunda yer alan öğrencilerin demografik özelliklerine göre (aldığınız dersler, eğitim dışında herhangi bir işle uğraşıyor musunuz? Elektronik cihazları (telefon, bilgisayar vb.) ne ölçüde kullanabileceğinizi düşünüyorsunuz? yaşadığın yerde yaşıyorsun İnternete erişim İnternet tabanlı öğrenme etkinliklere nereden giriyorsun?) Betimsel istatistiksel analizlerde frekans (f) ve yüzde (\%) teknikleri uygulanmaktadır. Öğrencileri planlamaya ve eğitmeye devam etmenin yanı sıra, çalışma durumlarına göre Mann Whitney U testi, elektronik cihaz kullanım ve internet erişim düzeyine göre Kruskal Wallis H testi kullanılmaktadır.

\section{C. Çalış̧ma Grubu/Evren ve Örneklem}

Araştırmada amaçlı örnekleme türlerinden uygun örnekleme yöntemleri dikkate alınarak bir araştırma ekibi oluşturulmuştur. Verilerin toplandığı çalışma grubunu 20202021 yılında Bursa Uludağ Üniversitesi Eğitim Fakültesi ve Eğitim Bilimleri Enstitüsünde öğrenim gören ve çalışmaya gönüllü olarak katılan 124 öğrenci oluşturmaktadır. Veri toplama aracını cevaplayan öğrencilerden dört tanesinin formu eksik cevaplaması nedeniyle çalışma grubuna dahil edilmemiştir. Çalışmaya 120 öğrenci ile devam edilmiştir. 
Eğitim Fakültesi Öğrencilerinin E-Öğrenmeye Yönelik Tutumlarının Incelenmesi

\section{Tablo 1}

Araştırma Örneklemindeki Öğrencilerin Demografik Özelliklere Göre Dă̆ılımı

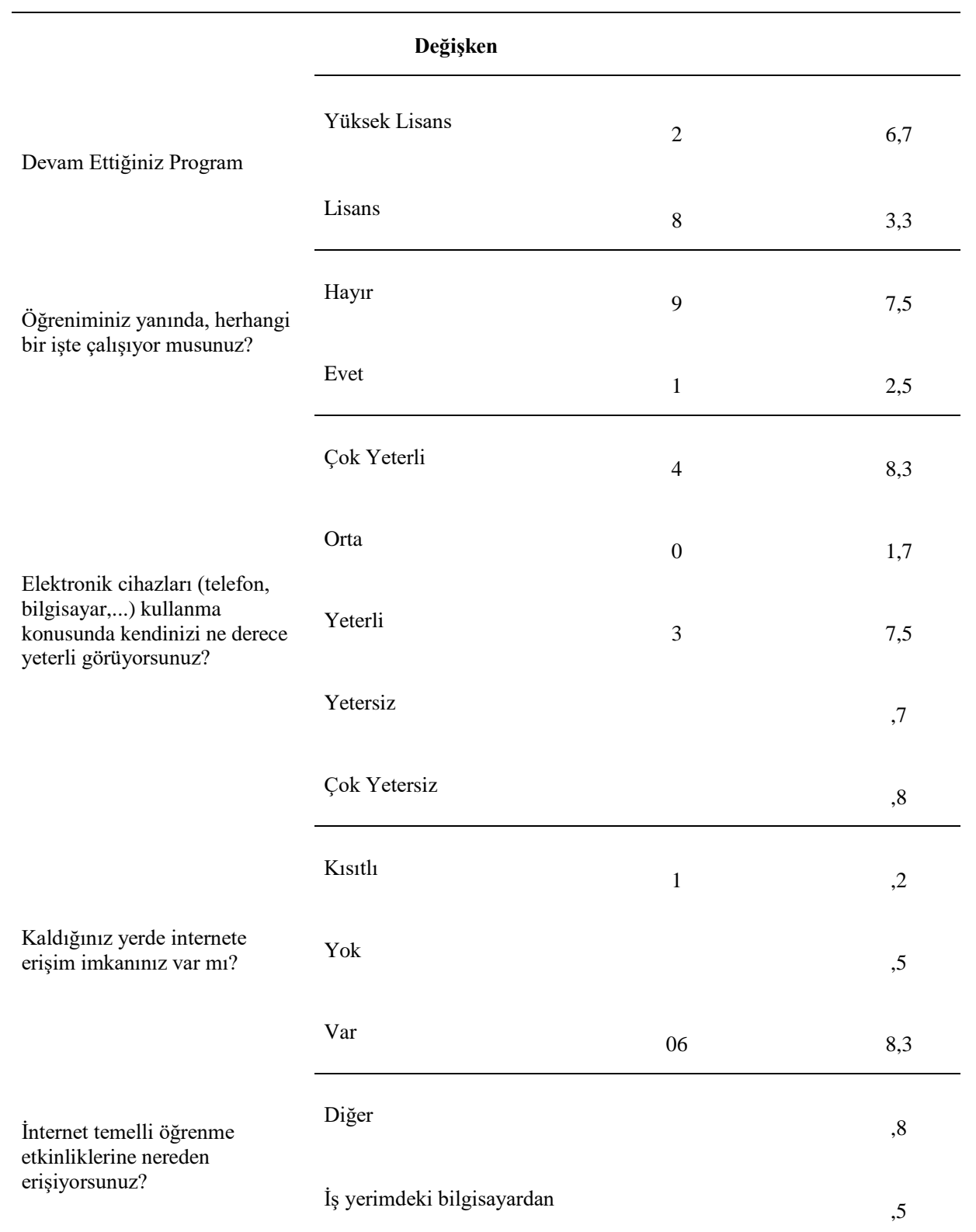


Tablo 1 incelendiğinde çalışma grubunun \%26,7'sini ( $\mathrm{n}=32)$ yüksek lisans öğrencileri, \% 73,3’ü (n=88)lisans ; \%57,5'inin(n=69) öğreniminin yanında herhangi bir işte çalışmadığ $1, \%$ 42,5'inin( $n=51)$ öğreniminin yanında herhangi bir işte çalıştı̆̆ elektronik cihaz kullanımına göre \%28,3'ü $(n=34)$ çok yeterli, \%41,7'si(n=50) orta, $\% 27,5$ 'i (n=33)yeterli, \%1,7'si(n=2) yetersiz, \%0,8'i $(n=1)$ çok yetersiz olduğu; kaldığ yerde internet erişim imkanına göre \%9,2'sinin(n=11) kısıtlı, \%2,5'inin(n=3) internet erişiminin olmadığ $1, \% 88,3$ 'ünün(n=106) internet erişiminin olduğu; internet temelli öğrenme etkinliklerine \%0,8'inin( $(n=1)$ diğer , \%2,5'inin $(n=3)$ işyerindeki bilgisayardan, $\% 2,5$ 'inin $(n=3)$ internet kafeden, \%94,2' $\operatorname{sinin}(n=113)$ evdeki bilgisayar/akıllı telefondan katıldığı görülmektedir.

\section{Bulgular}

Araştırmanın bu bölümünde, eğitim fakültesi öğrencilerinin e-öğrenmeye yönelik tutumlarının belirlenmesi amacı ve alt amaçları doğrultusunda elde edilen verilere ilişkin bulgular ve yorumlar sunulmuştur.

Demografik özellikler ve e-öğrenme tutum ölçeğinin alt boyutlarına ilişkin Mann Whitney U ve Kruskal Wallis-H testi bulguları;

\section{Tablo 2}

Öğrencilerin Teknoloji Kullanma ile Devam Edilen Program ve Herhangi Bir Isşte Çalışma Durumu Değişkenlerine İlişkin Mann Whitney U-testi Sonuçları

\begin{tabular}{|c|c|c|c|c|c|c|c|}
\hline & & & $\mathbf{N}$ & $\overline{\mathbf{X}}$ & S.S & $\mathbf{U}$ & $\mathbf{P}$ \\
\hline \multirow{5}{*}{$\begin{array}{l}\text { Teknoloji } \\
\text { Kullanma } \\
\text { Ĕgilimi }\end{array}$} & Devam Edilen & Lisans & 88 & 2,22 & 0,73 & \multirow{2}{*}{1232,000} & \multirow{2}{*}{0,29} \\
\hline & Progra & Yüksek Lisans & 32 & 2,10 & 0,78 & & \\
\hline & & & & & & \multirow[b]{3}{*}{1582,000} & \multirow[b]{3}{*}{0,34} \\
\hline & Öğrenimin & Evet & 51 & 2,28 & 0,77 & & \\
\hline & $\begin{array}{l}\text { Yanında, Herhangi } \\
\text { Bir İşte Çalışma } \\
\text { Durumu }\end{array}$ & Hayır & 69 & 2,12 & 0,72 & & \\
\hline
\end{tabular}


Tablo 2 'de gösterilmiş bulgulara göre teknoloji kullanma eğilimi ( $U=1232,000$, $\mathrm{p}=0,29)$ devam edilen programda öğrenim durumlarına göre anlamlı farklılık göstermemiştir. Teknoloji kullanma eğiliminde $(=2,22)$ lisans öğrencilerinin puanlarının daha yüksek olduğu görülmüştür. Teknoloji kullanma eğilimi ( $U=1582,000$, $\mathrm{p}=0,34)$ öğrenimin yanında, herhangi bir işte çalışma durumuna göre de anlamlı farklılık göstermemiştir. Teknoloji kullanma eğiliminde $(=2,28)$ öğrenimin yanında bir işte çalışanların puanlarının daha yüksek olduğu görülmüştür. Buna göre teknoloji kullanma eğilimi, devam edilen programa göre farklılık göstermemektedir. Öğrenimin yanında herhangi bir işte çalışanların teknoloji kullanma eğilimleri çalışmayanlara göre daha iyi olduğu söylenebilir.

Tablo 3

Öğrencilerin Memnuniyeti ile Devam Edilen Proram ve Herhangi Bir İşte Çalışma Durumu Değişkenlerine İlişkin Mann Whitney U-testi Sonuçları

\begin{tabular}{|c|c|c|c|c|c|c|c|}
\hline & & & $\mathbf{N}$ & $\overline{\mathbf{X}}$ & S.S & $\mathbf{U}$ & $\mathbf{P}$ \\
\hline \multirow{7}{*}{ Memnuniyet } & \multirow{3}{*}{ Devam Edilen Program } & Lisans & 88 & 2,53 & 0,75 & \multirow{3}{*}{583,000} & \multirow{3}{*}{0,00} \\
\hline & & & & & & & \\
\hline & & Yüksek Lisans & 32 & 3,36 & 0,65 & & \\
\hline & & & & & & & \\
\hline & \multirow{3}{*}{$\begin{array}{l}\text { Öğrenimin Yanında, } \\
\text { Herhangi Bir İşte } \\
\text { Çalışma Durumu }\end{array}$} & Evet & 51 & 3,03 & 0,78 & \multirow{3}{*}{1152,500} & \multirow{3}{*}{0,00} \\
\hline & & & & & & & \\
\hline & & Hayır & 69 & 2,55 & 0,78 & & \\
\hline
\end{tabular}

Tablo 3 'te gösterilmiş bulgulara göre programa devam eden lisans öğrencilerin memnuniyet düzeyleri ile programa devam eden yüksek lisans öğrencilerin memnuniyet düzeyleri arasında anlamlı farklılık olduğu görülmüştür $(U=583,000, p=0,00)$. Programa devam eden lisans öğrencilerin memnuniyet düzeyleri ile programa devam eden yüksek lisans öğrencilerin memnuniyet düzeyleri arasında programa devam eden yüksek lisans öğrencilerinin lehine anlamlı bir fark vardır. Öğrenimin yanında herhangi bir işte çalışanların memnuniyeti ile öğrenimin yanında herhangi bir işte çalışmayanların memnuniyeti arasında da anlamlı farklılık olduğu görülmüştür $(U=1152,500, p=.0,00)$. Öğrenimin yanında herhangi bir işte çalışanların memnuniyeti ile öğrenimin yanında herhangi bir işte çalışmayanların memnuniyeti arasında öğrenim görürken aynı zamanda çalışanların lehine anlamlı bir fark vardır. Buna göre yüksek lisans öğrencilerinin memnuniyet düzeylerinin daha yüksek olduğu söylenebilir. Öğrenimin yanında herhangi bir işte çalışan öğrencilerin memnuniyeti öğrenimin yanında herhangi bir işte çalışmayan öğrencilerden daha memnun sonucuna varılabilir. 
Sükrü $A D A$

A T A S OBED

1749 Sevil GÜLTEKIN

$202125(4): 1738-1761$

Hale GÖNENÇ

\section{Tablo 4}

Ögrrencilerin Motivasyonu ile Devam Edilen Program ve Herhangi Bir İşte Çalışma Durumu Değişkenlerine İlişkin Mann U-testi Sonuçları

\begin{tabular}{|c|c|c|c|c|c|c|c|}
\hline & & & $\mathbf{N}$ & $\overline{\mathbf{X}}$ & S.S & $\mathbf{U}$ & $\mathbf{P}$ \\
\hline \multirow{6}{*}{ Motivasyon } & \multirow{2}{*}{$\begin{array}{l}\text { Devam Edilen } \\
\text { Program }\end{array}$} & Lisans & 88 & 2,19 & 0,74 & \multirow{2}{*}{722,500} & \multirow{2}{*}{0,00} \\
\hline & & Yüksek Lisans & 32 & 2,95 & 0,83 & & \\
\hline & & & & & & & \\
\hline & Öğrenimin Yanında, & Evet & 51 & 2,70 & 0,80 & \multirow{3}{*}{1115,500} & \multirow{3}{*}{0,00} \\
\hline & Herhangi Bir İşte & & & & & & \\
\hline & Çalışma Durumu & Hayır & 69 & 2,16 & 0,79 & & \\
\hline
\end{tabular}

Tablo 4 'te gösterilmiş bulgulara göre programa devam eden lisans öğrencilerin motivasyon düzeyleri ile programa devam eden yüksek lisans öğrencilerin motivasyon düzeyleri arasında anlamlı farklılık olduğu görülmüştür $(U=722,500, p=0,00)$. Programa devam eden lisans öğrencilerin motivasyon düzeyleri ile programa devam eden yüksek lisans öğrencilerin motivasyon düzeyleri arasında programa devam eden yüksek lisans öğrencilerinin lehine anlamlı bir fark vardır. Öğrenimin yanında herhangi bir işte çalışanların motivasyonu ile öğrenimin yanında herhangi bir işte çalışmayanların motivasyonu arasında da anlamlı farklılık olduğu görülmüştür( $U=1115,500, p=0,00)$. Öğrenimin yanında herhangi bir işte çalışanların motivasyonu ile öğrenimin yanında herhangi bir işte çalışmayanların motivasyonu arasında öğrenim görürken aynı zamanda çalışanların lehine anlamlı bir fark vardır.Buna göre programa devam eden yüksek lisans öğrencilerinin motivasyon düzeyleri daha yüksektir denilebilir. Öğrenimin yanında herhangi bir işte çalışanların motivasyonları daha yüksek bulunmuştur.

\section{Tablo 5}

Kullanışlılık Alt Boyutu ile Devam Edilen Program ve Herhangi Bir Işste Çalışma Durumu Değişkenlerine İlişkin Mann Whitney U-testi Sonuçları

\begin{tabular}{|c|c|c|c|c|c|c|c|}
\hline & & & $\mathbf{N}$ & $\mathbf{X}$ & S.S & $\mathbf{U}$ & $\mathbf{P}$ \\
\hline \multirow{6}{*}{ Kullanışlılık } & \multirow{2}{*}{$\begin{array}{l}\text { Devam Edilen } \\
\text { Program }\end{array}$} & Lisans & 88 & 2,76 & 0,65 & \multirow{2}{*}{1193,500} & \multirow{2}{*}{0,20} \\
\hline & & Yüksek Lisans & 32 & 2,56 & 0,84 & & \\
\hline & & & & & & & \\
\hline & \multirow{3}{*}{$\begin{array}{l}\text { Öğrenimin Yanında, } \\
\text { Herhangi Bir İşte } \\
\text { Çalışma Durumu }\end{array}$} & Evet & 51 & 2,60 & 0,80 & \multirow{3}{*}{1543,500} & \multirow{3}{*}{0,25} \\
\hline & & & & & & & \\
\hline & & Hayır & 69 & 2,78 & 0,62 & & \\
\hline
\end{tabular}


Tablo 5 'te gösterilmiş bulgulara göre kullanışlılık alt boyutu ( $U=1193,500, p=0,20)$ devam edilen programda öğrencilerin öğrenim durumlarına göre anlamlı farklılık göstermemiştir. Kullanışlılık alt boyutunda $(=2,76)$ lisans öğrencilerinin puanlarının daha yüksek olduğu görülmüştür. Kullanışlılık alt boyutu ( $U=1543,500, p=0,25)$ öğrenimin yanında, herhangi bir işte çalışma durumuna göre de anlamlı farklılık göstermemiştir. Kullanışlılık alt boyutunda $(=2,78)$ öğrenimin yanında herhangi bir işte çalışmayanların puanlarının daha yüksek olduğu görülmüştür. Buna göre lisans öğrencileri ve herhangi bir işte çalışmayan öğrencilerin kullanışlılığa yönelik ortalamaları daha yüksektir.

\section{Tablo 6}

Teknoloji Kullanım Eğilimi ile Cihaz Kullanma Düzeyi ve İnternet Erişimine İlişkin Kruskal Wallis H-testi Sonuçları

\begin{tabular}{|c|c|c|c|c|c|c|}
\hline & & & $\mathbf{N}$ & $\mathbf{X}$ & $\mathbf{X} 2$ & $\mathbf{P}$ \\
\hline & & Çok Yetersiz & 1 & 0,01 & & \\
\hline & & Yetersiz & 2 & 3,08 & & \\
\hline & $\begin{array}{l}\text { Elektronik Cihaz } \\
\text { Kullanma Düzeyi }\end{array}$ & Orta Düzeyde Yeterli & 33 & 2,51 & 15,206 & 0,000 \\
\hline & & Yeterli & 50 & 2,1 & & \\
\hline & & Çok Yeterli & 34 & 1,96 & & \\
\hline \multirow[t]{4}{*}{$\begin{array}{l}\text { Teknoloji } \\
\text { Kullanım Eğitimi }\end{array}$} & \multirow{4}{*}{ İnternet Erişimi } & $\begin{array}{l}\text { Evimdeki Bilgisayar / } \\
\text { Akı1lı Telefon }\end{array}$ & 113 & 2,16 & \multirow{4}{*}{6,620} & \multirow{4}{*}{0,080} \\
\hline & & İnternet Cafeden & 3 & 2,94 & & \\
\hline & & $\begin{array}{l}\text { Üniversitenin } \\
\text { Sağladığı } \\
\text { Merkezlerdeki } \\
\text { Bilgisayarlardan }\end{array}$ & 1 & 0,01 & & \\
\hline & & $\begin{array}{l}\text { İş Yerimdeki } \\
\text { Bilgisayardan }\end{array}$ & 3 & 2,77 & & \\
\hline
\end{tabular}

Tablo 6 'da gösterilmiş bulgulara göre öğrencilerin elektronik cihaz kullanma düzeyi ile teknoloji kullanım eğilimi arasında $(X 2=15,206, p=0,00)$ anlamlı farklılık olduğu görülmüştür. Elektronik cihaz kullanma düzeyi ile teknoloji kullanım eğilimi arasında orta düzeyde elektronik cihaz kullanan öğrenciler lehine anlamlı fark olduğu 
görülmüştür. Fakat internet erişimi ile teknoloji kullanma eğilimi arasında $(X 2=6,620$, $\mathrm{p}=0,08$ ) anlamlı bir fark bulunmamaktadır ve internet erişimine, internet cafeden $(X=2,94)$ giriș sağlayanların daha yüksek ortalamaya sahip olduğu görülmüştür. Buna göre elektronik cihaz kullanma düzeyi yeterli olan öğrenciler teknoloji kullanmada daha yeterliler sonucuna varılabilir. İnternet erişimini, internet cafeden sağlayan öğrencilerin teknoloji eğilimi daha olumludur.

Tablo 7

Memnuniyet ile Elektronik Cihaz Kullanma Düzeyi ve İnternet Erişimine İlişkin Kruskal Wallis H-testi Sonuçları

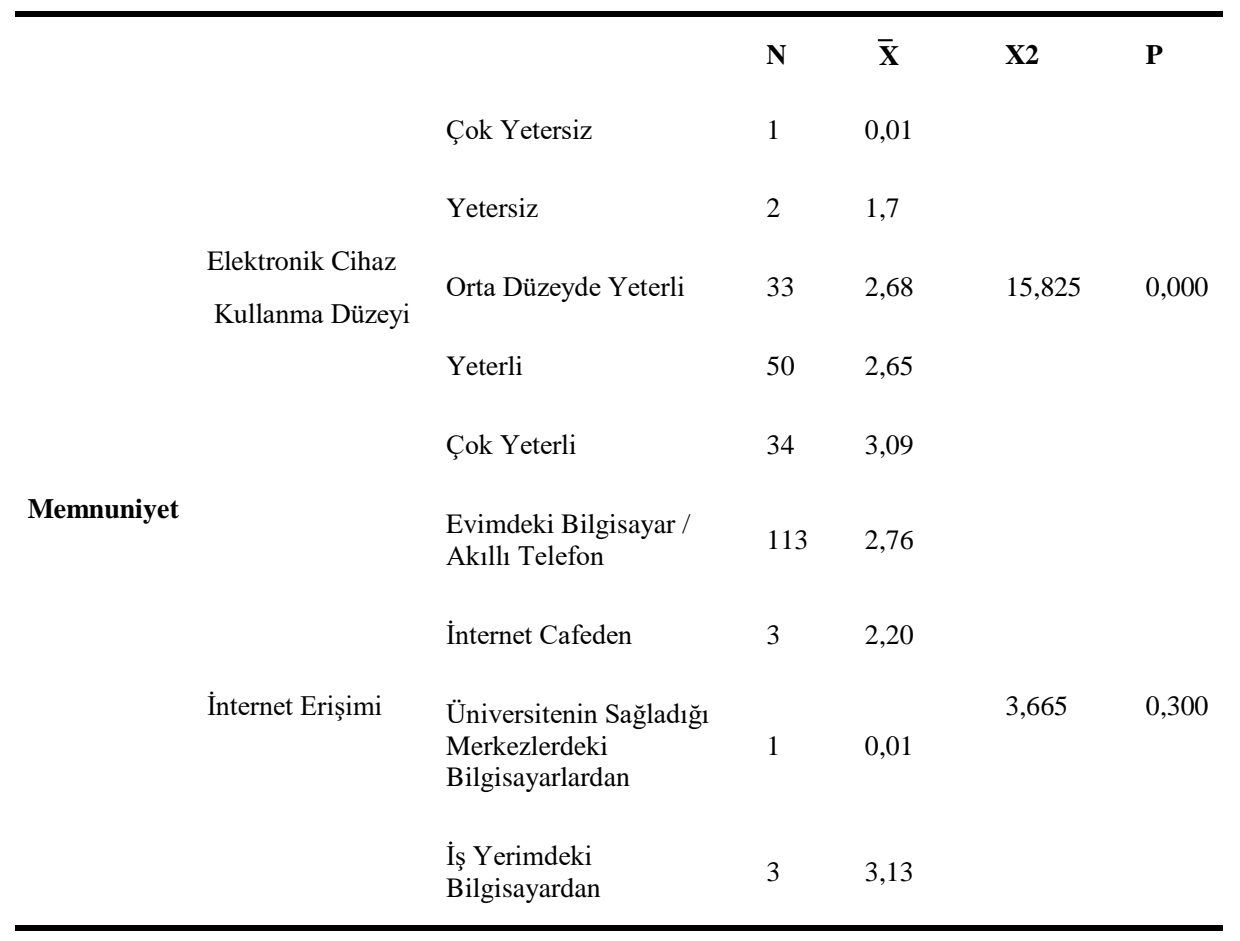

Tablo 7 'de gösterilmiş bulgulara göre öğrencilerin elektronik cihaz kullanma düzeyi ile memnuniyeti arasında $(\mathrm{X} 2=15,825, \mathrm{p}=0,00)$ anlamlı farklılık olduğu görülmüştür. Elektronik cihaz kullanma düzeyi ile memnuniyeti arasında çok yeterli düzeyde elektronik cihaz kullanan öğrenciler lehine anlamlı fark olduğu görülmüştür. Fakat internet erişimi ile memnuniyeti arasında $(\mathrm{X} 2=3,665, \mathrm{p}=0,30)$ anlamlı bir fark bulunmamaktadır ve internet erişimine, iş yerindeki bilgisayarlardan $(X=3,13)$ sağlayanların daha memnun oldukları görülmüştür. Buna göre elektronik cihazı çok 
Ĕ̆itim Fakültesi Öğrencilerinin E-Öğrenmeye Yönelik Tutumlarının Incelenmesi

yeterli kullanan öğrencilerin memnuniyet düzeyleri yüksektir. İnternet erişimini iş yerinden sağlayan öğrencilerin memnuniyet düzeyleri daha yüksek görülmektedir.

\section{Tablo 8}

Motivasyon ile Elektronik Cihaz Kullanma Düzeyi ve İnternet Erişimine İlişkin Kruskal Wallis H-testi Sonuçları

\begin{tabular}{|c|c|c|c|c|c|c|}
\hline & & & $\mathbf{N}$ & $\overline{\mathbf{X}}$ & $\mathbf{X} 2$ & $\mathbf{P}$ \\
\hline & & Çok Yetersiz & 1 & 0,01 & & \\
\hline & & Yetersiz & 2 & 1,33 & & \\
\hline & Elektronik Cihaz & Orta Düzeyde Yeterli & 33 & 2,34 & 8,160 & 0,086 \\
\hline & & Yeterli & 50 & 2,27 & & \\
\hline & & Çok Yeterli & 34 & 2,70 & & \\
\hline \multirow[t]{5}{*}{ Motivasyon } & & $\begin{array}{l}\text { Evimdeki Bilgisayar / Akıllı } \\
\text { Telefon }\end{array}$ & 113 & 2,40 & & \\
\hline & & İnternet Cafeden & 3 & 2,55 & & \\
\hline & İnternet Erişimi & & & & 1,013 & 0,798 \\
\hline & & $\begin{array}{l}\text { Üniversitenin Sağladığı } \\
\text { Merkezlerdeki Bilgisayarlardan }\end{array}$ & 1 & 0,01 & & \\
\hline & & İș Yerimdeki Bilgisayardan & 3 & 2,33 & & \\
\hline
\end{tabular}

Tablo 8'de gösterilmiş bulgulara göre öğrencilerin hem elektronik cihaz kullanma düzeyi $(\mathrm{X} 2=8,160, \mathrm{p}=0,08)$ hem de internet erişimi $(\mathrm{X} 2=1,103, \mathrm{p}=0,79)$ ile motivasyon arasında anlamlı fark bulunmamaktadır ve internet erişimine, internet cafeden $(X=2,55)$ sağlayanların daha motive oldukları görülmüştür. Buna göre internet erişimini internet cafeden erişim sağlayan öğrencilerin motivasyon düzeyleri daha yüksektir.

\section{Tablo 9}

Kullanışlllık ile Elektronik Cihaz Kullanma Düzeyi ve İnternet Erişimine İlişsin Kruskal Wallis H-testi Sonuçları

$\begin{array}{llll}\mathbf{N} & \overline{\mathbf{X}} & \mathbf{X} 2 & \mathbf{P}\end{array}$




\begin{tabular}{|c|c|c|c|c|c|c|}
\hline & & Çok Yetersiz & 1 & 0,01 & & \\
\hline & & Yetersiz & 2 & 3,66 & & \\
\hline & $\begin{array}{l}\text { Elektronik Cihaz } \\
\text { Kullanma Düzeyi }\end{array}$ & Orta Düzeyde Yeterli & 33 & 2,92 & 9,436 & 0,051 \\
\hline & & Yeterli & 50 & 2,63 & & \\
\hline & & Çok Yeterli & 34 & 2,57 & & \\
\hline Kullanışlılık & & $\begin{array}{l}\text { Evimdeki Bilgisayar / } \\
\text { Akıllı Telefon }\end{array}$ & 113 & 2,68 & & \\
\hline & & İnternet Cafeden & 3 & 3,50 & & \\
\hline & İnternet Erişimi & & & & 5,876 & 0,118 \\
\hline & & $\begin{array}{l}\text { Üniversitenin Sağladığı } \\
\text { Merkezlerdeki Bilgisayarlardan }\end{array}$ & 1 & 0,01 & & \\
\hline & & İş Yerimdeki Bilgisayardan & 3 & 3,05 & & \\
\hline
\end{tabular}

Tablo 9 'da gösterilmiş bulgulara göre öğrencilerin hem elektronik cihaz kullanma düzeyi $(\mathrm{X} 2=9,436, \mathrm{p}=0,05)$ hem de internet erişimi $(\mathrm{X} 2=5,876, \mathrm{p}=0,11)$ ile kullanışlılık arasında anlamlı fark bulunmamaktadır. Ayrıca internet erişimini, internet cafeden $(X=3,50)$ sağlayanlar daha kullanışlı bulmuşlardır. Buna göre internet erişimini, internet cafeden sağlayan öğrencilerin kullanışlılığa yönelik tutumları daha olumludur.

\section{Sonuç, Tartışma ve Öneriler}

Araştırmada Bursa Uludağ Üniversitesi Eğitim Fakültesi ve Eğitim Bilimleri Enstitüsünde öğrenim gören öğrencilerin e-öğrenmeye yönelik tutumları farklı değişkenler açısından incelenmiştir. Aşağıda araştırma hakkında bulgular alan yazınla desteklenmiş ve yorumlanmıştır.

Araştırmanın birinci alt problemi doğrultusunda elde edilmiş neticeye göre; teknoloji kullanma eğiliminde lisans öğrencilerinin ve öğrenimin yanında herhangi bir işte çalışanların tutumlarının daha olumlu olduğu görülmektedir. Orta düzeyde elektronik cihaz kullanma düzeyine sahip öğrencilerin teknoloji kullanma eğiliminin daha olumlu tutuma sahip olduğu görülmüştür. İnternet cafeden erişim sağlayan öğrenciler olumlu tutum sergilemektedir. Bu bulgu; Coşkun, Kaymakoğlu ve Gök (2007) araştırması ile benzerlik göstermekle birlikte tıp fakültesi öğrencilerinin e-öğrenme konusunda düşüncesinin olmadığı ve bu modeli kullanmak istemedikleri sonucuna ulaşılmıştır. Link \& Marz'ın (2006) araştırmasına benzer olmasına rağmen, birinci sınıf tıp öğrencilerinin büyük çoğunluğu interaktif ve multimedya ile geliştirilmiş öğrenme materyallerinin avantajlarını kabul etmek için yeterli bilgisayar becerilerine sahiptir ve e-öğrenmeye 
yönelik tutumları da bilgisayarlarda kullanılan ve daha önce kullanılan bilgisayarın sonucu, ikamet durumu gibi değişkenlerden etkilendiğidir.

Araştırmanın ikinci alt problemi doğrultusunda elde edilmiş bulgulara göre; yüksek lisans öğrencilerinin memnuniyet düzeylerinin daha yüksek olduğu görülmektedir. Öğrenim görürken aynı zamanda herhangi bir işte çalışan öğrencilerin memnuniyet düzeyleri daha yüksektir. Elektronik cihaz kullanma düzeyi çok yeterli olan öğrencilerin memnuniyet düzeyleri daha yüksektir. İnternet erişimini iş yerindeki bilgisayardan sağlayan öğrencilerin memnuniyet düzeyleri daha yüksek olduğu tespit edilmiştir. Bu bulgu Mohammadi, Hosseini \& Fami'nin (2011) araştırması ile tutarlı olmakla birlikte, öğretmenlerin e-öğrenme yöntemlerini öğretim yardımcıları olarak gördükleri ve eöğrenmeye karşı olumlu bir tutum içinde oldukları sonucuna varmışlardır. Sonuç olarak, e-öğrenmeye yönelik tutumları bilgisayar kullanımı ve internet kullanımı gibi değişkenlerden etkilenmektedir. Bu, Liaw, Huang \& Chen'in (2007) araştırmasıyla tutarlı olsa da araştırma sonuçları, e-öğrenme ortamının özerkliği, multimedya zenginliği ve öğretmenlerin rehberliği nedeniyle öğrencilerin e-öğrenme ortamı kişisel eğitimi teşvik etmektedir. Thakkar \& Joshi (2017) araştırmasına paralel olmasına rağmen, sonuç, mühendislik öğrencilerinin e-öğrenmenin kullanımına karşı çok olumlu bir tutuma sahip olduklarıdır. Özgür ve Tosun'un (2010) araştırması ile tutarsız olmasına rağmen, sonuç, lisans öğrencilerinin memnuniyetini sağlayan ağ destekli öğrenme ortamının öğretmen adaylarının çevrimiçi öğretime yönelik tutumlarını olumlu yönde geliştirdiğidir. $\mathrm{Bu}$ durum Kayalar, Koç, Başıüyük ve Kayalar'ın (2015) araştırması ile tutarsız olmakla birlikte, kendi bilgisayar, tablet ve akıllı telefonuna sahip olan üniversite öğrencilerinin çevrimiçi öğrenmeye daha meyilli oldukları ve bu cihazlar olmadan çevrimiçi öğrenmeye daha yatkın oldukları bulunmuştur.

Araştırmanın üçüncü alt problemi doğrultusunda elde edilmiş bulgulara göre; programa devam eden yüksek lisans öğrencilerinin motivasyon düzeylerinin daha yüksek olduğu görülmektedir. Öğrenim görürken aynı zamanda çalışanların motivasyon düzeylerinin daha yüksek olduğu görülmektedir. İnternet erişimine internet cafeden sağlayan öğrencilerin motivasyon düzeylerinin daha yüksek olduğu tespit edilmiştir. Bu bulgular; Sitepu (2019)'un çalışmasında lisans öğrencilerinin e-öğrenme planına uyum sağlamada zorluk yaşadıkları ve ders kitabını ve değerlendirme sürecini anlamakta zorlandıklarıdır. Ayrıca öğrencilerin e-öğrenme planında okuma ödevleri verme ve değerlendirme konusunda olumsuz bir tutuma sahip olmalarına sebep olmaktadır. $\mathrm{Bu}$ durum Haznedar'ın (2012) araştırmasıyla tutarlı olmakla birlikte, üniversite öğrencilerinin e-öğrenmeye karşı tutumlarının internet kullanım sıklığına, öğrenme yöntemlerine, çalışma biçimlerine, öğrenme stillerine ve motivasyon türlerine göre farklılık gösterdiği, fakat akademik başarı ve bilgisayar kullanma deneyimi, ikisi arasında önemli bir fark yoktur. Bu durum Çetin'in (2018) araştırması ile tutarsız olmakla birlikte, bilgisayar deneyimi değişkenlerinden dolayı öğrencilerin e-öğrenmeye yönelik tutumlarının farklı olmadığı sonucuna ulaşılmıştır.

Araştırmanın dördüncü alt problemi doğrultusunda elde edilmiş bulgulara göre; lisans öğrencilerinin ve öğrenimin yanında herhangi bir işte çalışmayanların eöğrenmenin kullanışlılığına yönelik tutumları daha yüksek görünmektedir. İnternet 
erişimini internet cafeden sağlayan öğrencilerin e-öğrenmenin kullanışlılığına yönelik tutumlarının daha yüksek olduğu tespit edilmiştir. Bu bulgular; Liaw, Huang \& Chen (2007) 'nin araştırmasıyla tutarlı olsa da, e-öğrenmenin öz-yeterlik, zevk, yararlılık ve davranış kullanma niyeti gibi davranışları içerdiği ve e-öğrenme ortamının olumlu etki sergilediği sonucuna varılmıştır. İnsanların yararlı öğretim yardımcıları olarak kullanılmaya yönelik tutumları oluşmuştur. Adewole-Odeshi (2014) çalışmasına paralel olarak, öğrencilerin e-öğrenme sistemlerini kullanmanın basit ve kullanışlı buldukları ve algılanan bu avantajın e-öğrenme sistemlerini kullanmaya yönelik tutumlarını pozitif yönde etkilediği sonucuna varılmıştır.

Teknolojinin gelişmesi ve internetin hayatın bir parçası haline gelmesiyle eöğrenmenin giderek daha fazla kabul görmesini sağlamıştır. E-öğrenme öğrencilerin hayatında önemli bir edinmiştir. Avantaj ve dezavantajları bulunmakla birlikte araştırma sonucunda yüksek lisans öğrencilerinin daha fazla memnun ve motivasyonlarının daha yüksek olmasının sebebi kişisel gelişimlerini ve mesleki yeterliliklerini artırma firsatını elde etmiş olmaları olabilir. Lisans öğrencileri ve eğitim yanında bir işle ilgilenmeyen öğrencilerinin e-öğrenmeye yönelik tutumlarının daha yüksek çıkmasının sebebi akademik gelişimlerine daha fazla zaman ayırabilmeleri olabilir. İnternet kafelerden internet erişimi sağlayan öğrencilerin e-öğrenmenin kullanışlılığına yönelik tutumlarının daha yüksek olmasının sebebi ikametlerinden internete erişim sağlayamıyor olmaları olabilir. Elektronik cihaz kullanımında kendini yeterli gören öğrencilerin daha fazla memnun olmalarının sebebi kendilerine ait elektronik cihaz olması olabilir.

Covid-19 salgını ile birlikte yüz yüze eğitim askıya alınmış ve e-öğrenme araçları ile yapılan uzaktan eğitimin hayatımızda yer almasını sağlamıştır. Teknolojik imkânlara bağlı olarak da öğrenme ortamlarını elektronik ortama taşımak zorunda kalınmıştır. Eöğrenme alternatif bir yöntem olmaktan çıarak tek çözüm yolu olarak görülmüştür.

Araştırma sonucunda elde edilmiş bulgulara dayanarak erişilen sonuçlar aşağıdaki gibi stralanabilir:

1.Teknolojiyi kullanma eğiliminde, lisans öğrencilerinin ve eğitim dışında herhangi bir işle uğraşanların tutumlarının daha olumlu olduğu görülmektedir. Elektronik cihazları orta düzeyde kullanan öğrencilerin teknolojiyi kullanmaya yönelik daha olumlu bir tutuma sahip oldukları görülmektedir. İnternet kafeye giren öğrenciler olumlu bir tavir sergilemektedir.

2.Yüksek lisans öğrencilerinin memnuniyetinin görece yüksek olduğu görülmektedir. Herhangi bir işte çalışan ve aynı anda okuyan öğrenciler daha memnundur. Elektronik cihazları yeterince kullanan öğrenciler daha yüksek bir memnuniyet düzeyine sahiptir. İş yerinde bilgisayar aracıllğıyla internete erişen öğrencilerin yüksek düzeyde memnuniyet duydukları tespit edilmiş̧ir.

3.Programa devam eden yüksek lisans öğrencilerinin motivasyonlarının daha yüksek olduğu görülmüştür. Öğrenme sürecinde, çalışanların daha yüksek bir motivasyona sahip olduğu görülmektedir. İnternet kafeler aracılığıyla internete erişim sağlayan öğrencilerin motivasyonlarının daha yüksek olduğu belirlenmiştir. 
4. Lisans öğrencileri ve eğitim dışında bir işi olmayanlar, e-öğrenmeye karşı oldukça yüksek bir tutuma sahip oldukları sonucuna varılmıştır. İnternet kafelerden internet erişimi sağlayan öğrencilerin e-öğrenmenin kullanışlılığına yönelik tutumlarının daha yüksek olduğu belirlenmiştir.

\section{A. Öneriler}

Aşağıda araştırma kapsamında elde edilen bulgulara dayalı olarak öneriler sunulmaktadır.

1. Bu araştırmada, aynı zamanda herhangi bir işle uğraşan ve aynı zamanda okuyan lisansüstü öğrenci ve öğrencilerin daha yüksek motivasyon ve doyuma sahip oldukları tespit edilmiştir. Bu durumda motivasyon ve memnuniyeti sürdürmek için üniversitenin öğretim stratejilerini öğrencilerin ihtiyaçlarına göre uyarlayarak, öğrencilere danışabilecek bölümler kurarak ve motivasyon web seminerleri düzenleyerek olası engelleri aşmak mümkündür.

2. Yüksek lisans ve öğrenim sürecinde dersi almaya ve çalışmaya devam eden öğrencilerin motivasyonunun daha yüksek olacağı belirlenmiştir. Bu durumda üniversiteler, çalışanların eğitim hayatlarına devam etmelerine ve kariyerlerine odaklanmalarına ve yeteneklerini geliştirmelerine yardımcı olacak farklı kurslar sunarak kurs süresi düzenleyebilir.

3. Elektronik cihazları orta düzeyde kullanan öğrencilerin teknoloji kullanımına yönelik daha pozitif bir tutuma sahip oldukları belirlenmiştir. Bu durumda, pandemik sürecin daha uzun sürebileceği göz önünde bulundurularak üniversitelerin çevrimiçi bir sosyal platform oluşturarak öğrencilere teknolojik donanım kullanma becerisi konusunda eğitim vermeleri önerilmektedir.

4. İnternet kafelerden internet erişimi sağlayan öğrencilerin e-öğrenmenin pratikliğine yönelik tutumlarının daha yüksek olduğu belirlenmiştir. Bu nedenle, yerel yönetimlerin evde internet erişimi sağlamak için altyapı yatırımlarını artırmaları önerilmektedir.

\section{Kaynaklar}

UNESCO. (2020, 11 28). Global monitoring of school closures caused by Covid-19. https://en.unesco.org/covid19/educationresponse adresinden alınmıştır.

Alkan, C. (2019). Öğrenme Sürecinde İlkeler. Ankara Univeritsy of Faculty Educational Sciences (JFES) , 209-229.

Anadolu Ajans1. (2020, 4 20). Pandemi Günlerinde Türk Yüksekögrretimi. Covid 19 Bilgilendirme: https://covid19.yok.gov.tr/Sayfalar/HaberDuyuru/pandemigunlerinde-turk-yuksekogretimi.aspx adresinden alınmıştır

Arat, T. (2011). İletişim teknolojilerinin yükseköğrenim kurumlarında öğreim amaçlı kullanımı:Selçuk Üniversitesi Örneği(Yayınlanmamış Doktora Tezi). Selçuk Üniversitesi Sosyal Bilimler Enstitüsü. 
Arslan, S., \& Kurbanoglu, İ. (2018). Investigation of the Relationship between ELearning and Cooperative Learning Attitudes of High School Students. Journal of Education and Future, 107-117.

Aslan, Ö. (2006). Öğrenmenin yeni yolu:E-öğrenme. Firat Üniversitesi SosyalBilimler Dergisi, 16(2),121-131.

Atasoy, R., Özden, C., \& Kara, D. N. (2020). Covid-19 Pandemi Sürecinde Yapılan EDers Uygulamalarının Etkililiğinin Öğrencilerin Perspektifinden Değerlendirilmesi. Turkish Studies, 15(6), 95-122.

Azzi-Huck, K., \& Shmis, T. (2020, 11 25). Managing the impact of COVID-19 on education systems around the world: How countries are preparing, coping, and planning for recovery. https://blogs.worldbank.org/education/managing-impactcovid-19-educationsystems-educationsystems- adresinden alınmıştır

Babuçoğlu, B. (2006). İnternet destekli olarak sunulan muhasebe uygulamaları dersinde öğrenci memnuniyetinin ölçülmesi:Özelİnci Anadolum Açıköğretim kursunda bir uygulama(Yayınlanmamış Yüksek Lisans Tezi). Anadolu Üniversitesi,Sosyal Bilimler Enstitüsü.

Bach, S., Haynes, P., \& Smith, J. L. (2006). Online Learning and Teaching in Higher Education. UK:McGraw-Hill Education.

Bahçekapılı, E. (2010). Eş zamanlı çevrimiçi bir öğrenme ortamı tasarımı.(Yayınlanmamış Yüksek Lisans Tezi). Karadeniz Teknik Üniversitesi,Fen Bilimleri Enstitüsü.

Balc1, A. (2015). Sosyal Bilimlerde Araştırma Yöntem,Teknik ve Illkeler. Pegem Akademi.

Balcı, B. (2011a). E-öğrenme program tasarım süreçleri.G.Telli Yamamoto,U.Demiray ve M.kESIM (Ed.),Türkiye'de e-öğrenme:Gelişmeler ve uygulamalar içinde(6588.ss.). Elif Yayınevi.

Biçer , H. (2019). E-Öğrenmeye Yönelik Tutum: Ölçek Uyarlama Çalışması1(Yüksek Lisans Tezi). Necmettin Erbakan Üniversitesi Eğitim Bilimleri Enstitüsü.

Camnalbur, M. (2008). Bilgisayar destekli öğretimin etkililiği üzerine bir meta analiz çalışması (Yayınlanmamış Yüksek Lisans Tezi). Marmara Üniversitesi,Eğitim Bilimleri Enstitüsü.

Can, A. (2019). SPSS ile Bilimsel Araştırma Sürecinde Nicel Veri Analizi. Pegem Akademi.

Can, Ş. (2008). Fen Eğitiminde Web Tabanlı Eğitim,Yüksek Lisans Tezi, Manisa, 2025.

Coşkun, G., Kaymakoğlu, B., \& Gök, E. (2007). Tıp Fakültesi Öğrencilerinin İnternet Kullanımı ve E-öğrenme’ye İlişkin Tutumları. Başkent Üniversitesi Uygulaması. 
Ĕ̆itim Fakültesi Öğrencilerinin E-Öğrenmeye Yönelik Tutumlarının Incelenmesi

Creswell, N. K. (2014). Araştırma Deseni: Nitel,Nicel ve Karma Yöntem Yaklaşımları(S.B.Demir,çev.). Eğiten Kitap.

Cura, T. (2009). Yöneticiler için bilişim teknolojileri ve enformasyon sistemleri. Sistem Yayıncılı.

Çalışkan, Ş. (2019). Çevrimiçi öğrenme ortamının kullanılabilirlik analizi ve etkililiği:Ahmet Yesevi Üniversitesi Örneği (Yayınlanmamış Yüksek Lisans Tezi). Necmettin Erbakan Üniversitesi, Eğitim Bilimleri Enstitüsü.

Çetin, U. (2018). Denizcilik Lisesi Öğrencilerinin E-Öğrenmeye Yönelik Tutumlarının Farklı Değişkenler Açısından Incelenmesi. Yüksek Lisans Tezi. Bahçeşehir Üniversitesi, Eğitim Bilimleri Enstitüsü.

Demir, M. (2013). Eğitim Fakültesi Örencilerinin E- öğrenme Araçlarını Kabul Düzeylerinin Çeşitli Değişkenler Açısından İncelenmesi(Yayınlanmamış Yüksek Lisans Tezi). Sakarya Üniversitesi,Eğitim Bilimleri Enstitüsü.

Dikbaş, E. (2006). Öğretmen adaylarının e-öğrenmeye yönelik tutumlarının incelenmesi.(Yayınlanmamış yüksek lisans tezi). Dokuz Eylül Üniversitesi,Eğitim Bilimleri Enstitüsü.

Duygun, M. (2020, Kasım 13). Üniversite Öğrencileri Uzaktan Ĕ̈itimi Verimsiz Buluyor. https://haberuskudar.com/. adresinden alınmıştır

Engin, A., Tösten, R., \& Kaya, M. D. (2010). Bilgisayar Destekli Eğitim. Sosyal Blimler Dergisi, 5, 69-80.

Erturgut, R. (2008). İnternet temelli uzaktan eğitimin örgütsel,sosyal,pedagojik ve teknolojik bileşenleri. Bilişim Teknolojileri Dergisi, 1(2),79-85.

Fry, K. (2001). E-learning markets and providers:some issues and prospects. Education Training, 4(5), 233-239.

Govindasamy, T. (2002). Successful İmplementation of E- learning Pedagogical Considerations. Internet and Higher Education, 4, 287-299.

Gökdaş, İ., \& Kayri, M. (2005). E-öğrenme ve Türkiye Açısından Sorunlar,Çözüm Önerileri. Yüzüncü Yıl Üniversitesi Eğitim Fakültesi Dergisi, 2(2),1-20.

Gülbahar. (2012). E-Öğrenme Ortamlarında Katılımcıların Hazır Bulunuşluk ve Memnuniyet Düzeylerinin Ölçülmesi için Ölçek Geliştirme Çalışması. Ankara Üniversitesi Ĕgitim Bilimleri Fakültesi Dergisi, 45(2):119-137.

Gülbahar, Y. (2021). E-Öğrenme. Pegem Akademi.

Gürsoy, F. (2014). Kalıp hazırlama teknikleri öğretiminde akıllı tahtaya dayalı yüz yüze ögrretim ve e-öğrenme uygulamalarının öğrencilerin başarı, beceri ve tutumlarına etkisi. Doktora tezi. Necmettin Erbakan Üniversitesi,Eğitim Bilimleri Enstitüsü.

Haznedar, Ö. (2012). Üniversite Öğrencilerinin Bilgi ve İletişim Teknolojileri Becerilerinin ve E-Öğrenmeye Yönelik Tutumlarının Farklı Değişkenler Açısından 
İncelenmesi. (Yüksek Lisans Tezi). Dokuz Eylül Üniversitesi, Eğitim Bilimleri Enstitüsü.

Holder, B. (2007). An investigation of hope, academics, environment, and motivation as predictors of persistence in higher education online programs. . The Internet and Higher Education, 10, 245-260.

Karahisar, D. (1999). İnternet Ortamında Eğitim. Kuram ve Uygulamada Eğitim Yönetimi, 18(18),145-168.

Karasar, N. (2020). Bilimsel Araştırma Yöntemleri. Nobel Yayın Dağıtım.

Kayalar, M. T., Koç, A., Başıbüyük, B., \& Kayalar, F. (2015). Öğretmen Adaylarının EÖğrenmeye Yönelik Tutumlarının Belirlenmesi: Erzincan Üniversitesi Örneği. 3. Uluslararası Teknoloji ve Öğretmen Eğitimi Sempozyumu (ITTES), (s. 9-11). Trabzon.

Kesim, M. (2002). Herkes için, her yerde, her zaman etkin öğrenim ,e-öğrenme. Açık ve Uzaktan Eğitim Sempozyumu. 23-25 Mayıs, Eskişehir.

Khan, B. H., \& Joshi, V. (2006). E-learning who, what and now? Journal of Creative Communications, 4, 61-74.

Kırık, A. M. (2014). Uzaktan eğitimin tarihsel gelişimi ve Türkiye'deki durumu. Marmara İletişim Dergisi, 21, 73-94.

Kisanga, D. (2016). Determinants of teachers' attitudes towards e-learning in Tanzanian higher earning institutions. International Review of Research in Open and Distributed Learning, 54, 109-125.

Klein, H. J., Noe, R. A., \& Wang, C. (2006). Motivation to learn and course outcomes:The impact of delivery mode, learning goal orientation, and perceived barriers and enablers. Personnel Psychology, 59, 665-703.

Liaw, S., Huang, H., \& Chen, G. (2007). An activity-theoretical approach to investigate learners' factors toward e-learning systems. Computers in Human Behavior, 19061920.

Link, T. M., \& Marz, R. (2006). Computer literacy and attitudes toward e-learning among first year medical students. BMC medical education, 34 .

Machado, C. (2007). Developing an e-readiness model for higher education institutions: results of a focus group study. British Journal Of Educational Technology, 38(1),7282.

Mohammad1, D., Hossein1, S., \& Fam1, H. (2011). Investigating Agricultural Instructors' Attitudes Toward E-Learning In Iran. Turkish Online Journal of Distance Education, $1,174-183$.

Moore, M. G., \& Kearsley, G. (2012). Distance education:Asystems view of online learning. Belmont,CA:Wadswort,Cengage Learning. 
Ĕ̆itim Fakültesi Öğrencilerinin E-Öğrenmeye Yönelik Tutumlarının Incelenmesi

Mountz, A. (2020, Ekim 12). What's Student Life Like During a Pandemic. https://news.psu.edu/story/ adresinden alınmıştır

Nalbant, B. (2006). Elektronik Öğrenmenin İşletmelerde Kullanımı ve Çalışanların Eloktronik Öğrenmeye Karşı Tutumlarının Belirlenmesi(Yayınlanmamış Yüksek Lisans Tezi). Çanakkale Onsekiz Mart Üniversitesi, Sosyal Bilimler Enstitüsü.

Odabaş, H. (2003). İnternet tabanlı uzaktan eğitim ve bilgi ve belge yönetimi bölümleri. Türk Kütüphaneciliği Dergisi, 17(1), 22-36.

Olpak, Y. Z. (2010). Çevrimiçi öğrenme ortamlarında kullanılan farklı etkileşim araçlarının öğrencilerin başarılarına ve sosyal bulunuşluk algılarına etkisi(Yayınlanmamış YüksekLisans Tezi). Gazi Üniversitesi,Ĕgitim Bilimleri Enstitüsü.

Özbay, Ö. (2015). Dünya'da ve Türkiye'de Uzaktan Eğitimin Güncel Durumu. Uluslararası Ĕgitim Bilimleri Dergisi, 4, 377-394.

Özgür, H., \& Tosun, N. (2010). İnternet destekli eğitimin e-öğrenme tutumlarına etkisi. XV.Türkiye'de Internet Konferansı, (s. 2-4).

Özkaraca, O. (2005). İnternet Tabanlı Güç Elektroniği Eğitimi,Yüksek Lisans Tezi, Ankara. s: 8-16.

Paechter, M., Maier, B., \& Macher, D. (2009). Students' expectations of, and experiences in e-learning: Their relation to learning achievements and course satisfaction. Computers \& Education, 222-229.

Pena, M., \& Yeung, A. (2010). Satisfaction with Online Learning: Does Students' Computer Competence Matter? International Journal Of Technology, Knowledge \& Society, 6(5),97-108.

Sarıtaş, E., \& Barutçu, S. (2020). Öğretimde Dijital Dönüşüm ve Öğrencilerin Çevrimiçi Öğrenmeye Hazır Bulunşluluğu: Pandemi Döneminde Pamukkale Üniversitesi Öğrencileri Üzerinde Bir Araştırma. Internet Uygulamalrı ve Yönetimi, 11(1), 6-22.

Sitepu, S. S. (2019). Students' Attitude Towards Assigment and Assessment in Reading: an Overview of Elearning. Lexeme: Journal of Linguistics and Applied Linguistics, 1 .

Şişman, M. (2007). Eğitim Bilimlerine Giriş. Pegem Yayınları.

Talan, T. (2018). Dönüştürülmüş sınıf modeline göre e-öğrenme ortamının tasarımı ve modelin uygulanabilirliğinin değerlendirilmesi(Yayınlanmamış Doktora Tezi). İstanbul Üniversitesi, Fen Bilimleri Enstitüsü.

Telli Yamamoto, G., \& Altun, D. (2020). Coronavirüs ve Çevrimiçi(online) Eğitimin Önlenemeyen Yükselişi. Üniversite Araştırmaları Dergisi, 3(1),25-34.

Thakkar, S., \& Joshi, H. (2017). Students' Attitude towards E-learning. International Journal of Advance Engineering and Research Development, 11. 
Tuzem. $\quad(2009,11 \quad$ 03). Web:htpp://tuzem.trakya.edu.tr/e_ogrenme.html. htpp://tuzem.trakya.edu.tr/e_ogrenme.html adresinden alınmıştır

Usta, E. (2007). Harmanlanmış öğrenme veçevrimiçi öğrenme ortamlarının akademik başarı ve doyuma etkisi(Yayınlanmamış Doktora Tezi). Gazi Üniversitesi,Ĕgitim Bilimleri Enstitüsü.

Uzaktan Eğitim Taslak Raporu. (2004). http://bilisimsurasi.org.tr adresinden erişilmiştir.

Ütüner, M. (2006). Öğretmenlik Mesleğine Yönelik Tutum Ölçeğinin Geçerlik ve Güvenirlik Çalışması. Kuram ve Uygulama da Eğitim Yönetimi Dergisi, 45, 112.

Wahlstedt, A., Pekkola, S., \& Niemela, M. (2008). From E-learning Space to E-learning Place. British Journal of Education Technology, 39(6),1020-1030.

Yang, C. C., Tsai, I. C., Kim, B., Cho, M. H., \& Laffey, J. M. (2006). Exploring the relationships between students' academic motivation and social ability in online learning environments. The Internet and Higher Education, 9(4),277-286.

Zhan, Z., \& Mei, H. (2013). Academic self-concept and social presence in face-to-face andonline learning: Perceptions and effects on students' learning achievement and satisfaction across environments. Computers \& Education, 69, 131-138. 